\title{
Van baan naar baanmobiliteit bij laagopgeleide 45-plussers
}

\author{
Jos Sanders, Ellen van Wijk, Oleg Boneschansker \& Jan Fekke Ybema*
}

\begin{abstract}
Langer doorwerken vormt een belangrijke uitdaging voor laagopgeleide 45-plussers. Verandering van baan is daarbij een zinvolle, soms zelfs noodzakelijke, strategie. Vrijwillige externe mobiliteit is echter onder laagopgeleide 45-plussers zeldzaam. In deze bijdrage staat de vraag centraal of de versterking van vertrouwen in eigen kunnen (self-efficacy) bij het vinden van een nieuwe werkgever een aangrijpingspunt is voor bevordering van vrijwillige externe mobiliteit onder laagopgeleide 45- tot 64-jarige werknemers. Om de vraag te beantwoorden gebruiken we data van 11.987 werknemers van 45 tot 64 jaar, van wie er 3.212 laagopgeleid zijn. De data zijn afkomstig van de Study on Transitions in Employment, Ability and Motivation (STREAM). Uit het onderzoek blijkt dat vertrouwen in eigen kunnen een positief verband heeft met zowel de intentie tot baanverandering als met daadwerkelijke baanverandering. Hoger opgeleide 45-plussers blijken hoger te scoren op zowel vertrouwen in eigen kunnen als op intentie tot baanverandering. De relatie tussen beide concepten verschilt echter niet tussen laag- en hoger opgeleiden. Deze bevinding impliceert dat versterking van het vertrouwen bij laagopgeleide 45-plussers in een succesvolle baan-baantransitie kan leiden tot een versterking van de vrijwillige externe mobiliteit. Een belangrijke vervolgvraag is dan of die mobiliteit ook tot een minder kwetsbare arbeidsmarktpositie leidt.
\end{abstract}

\section{Inleiding en probleemstelling}

De (werkende) beroepsbevolking in Nederland wordt ouder. Bedroeg de gemiddelde leeftijd van de werkenden in Nederland in 1990 nog 36,6 jaar en in 2000 38,1 jaar, in 2010 was deze toegenomen tot 40,1 jaar (CBS Statline, 2011). Als gevolg van deze veroudering wordt in de komende decennia een tekort aan arbeidskrachten verwacht (Europese Commissie, 2008). Om het tekort aan arbeidskrachten op te vangen en de welvaartsstaat in de toekomst betaalbaar te houden is het belangrijk dat het beschikbare arbeidspotentieel optimaal wordt benut en dat meer werknemers langer productief blijven op de arbeidsmarkt; duurzaam inzetbaar dus. Alle werknemers en hun werkgevers zullen daarom ook $\mathrm{nu}$ al moeten nadenken over manieren om de verduurzaming van inzetbaarheid te verhogen. Duurzame inzetbaarheid wordt hier gedefinieerd als gezond en productief kunnen doorwerken tot de pensioengerechtigde leeftijd.

* Jos Sanders is werkzaam bij TNO Work \& Employment, Hoofddorp, e-mailadres: jos.sanders@tno.nl. Ellen van Wijk is werkzaam bij TNO Work \& Employment, Hoofddorp. Oleg Boneschansker is werkzaam bij TNO Work \& Employment, Hoofddorp. Jan Fekke Ybema is werkzaam bij TNO Work \& Employment, Hoofddorp. 
De versobering van de mogelijkheden voor vervroegd uittreden hebben in de afgelopen jaren bijgedragen aan een toename van de gemiddelde pensioenleeftijd en de arbeidsparticipatie van oudere werknemers. De arbeidsparticipatie van oudere werknemers blijft echter nog fors achter bij de algemene arbeidsdeelname (Otten et al., 2010) en de gemiddelde pensioenleeftijd ligt in Nederland in 2010 nog altijd op 'slechts' 62 jaar. Bovendien blijkt $80 \%$ van de Nederlandse werknemers vóór het 65 ste levensjaar met pensioen te gaan en $60 \%$ geeft aan niet te willen doorwerken tot het 65ste levensjaar (Otten et al., 2010).

Hoewel er dus vooruitgang wordt geboekt als het gaat om langer doorwerken, blijft voor veel oudere werknemers (en hun werkgever) de verduurzaming van de eigen inzetbaarheid een duidelijke uitdaging. We richten ons in deze studie daarom op 45 -plussers. Voor laagopgeleide ${ }^{1} 45$-plussers lijkt verduurzaming van de inzetbaarheid een extra uitdaging (zie ook Kraan et al., 2011). Deze groep heeft in het algemeen een minder goede gezondheid (CBS, 2008), kampt vaker met één of meer chronische aandoeningen, werkt vaker in fysiek zwaar belastende beroepen en is vaker ziek, wat leidt tot tijdelijke arbeidsmarktuittrede of langdurige werkloosheid (Nicoletti \& Peracchi, 2001; Phillipson \& Smith, 2005; Henkens et al., 2009). Laagopgeleiden werken bovendien relatief vaak in tijdelijke banen, in conjunctuurgevoelige sectoren en met een geringere baan- en werkzekerheid (De Vries et al., 2004). Ten slotte blijkt uit onderzoek dat laagopgeleiden een verhoogd risico lopen dat hun werk of delen ervan worden geoutsourcet, geautomatiseerd of geoffshored, waardoor de bij hen aanwezige kennis en vaardigheden hun waarde verliezen voor de Nederlandse arbeidsmarkt en verlies van baan en werk dreigen (De Grip \& Van Loo, 2002; De Beer, 2006; Görlich \& De Grip, 2007; Steemers, 2010). Verandering van baan lijkt daarom een zinvolle, soms noodzakelijke strategie voor de duurzame inzetbaarheid van laagopgeleiden. Recent onderzoek laat echter zien dat laagopgeleide werknemers minder baanbaanmobiliteit laten zien dan hoger opgeleiden (Gesthuizen \& Dagevos, 2005; Zwinkels et al., 2009; Sanders et al., 2011c). Bovendien zijn laagopgeleiden meer gericht op de interne arbeidsmarkt. Ook blijken laagopgeleiden eerder te willen stoppen met werken dan hoger opgeleiden (Henkens et al., 2009; Ybema et al., 2011b). Als laagopgeleiden mobiel worden, dan is dat vooral gedwongen, bijvoorbeeld door een reorganisatie of een conflict (Hooftman et al., 2011). De vraag is waarom laagopgeleiden minder baan-baanmobiliteit laten zien dan hoger opgeleiden.

Baan-baanmobiliteit wordt door diverse factoren beïnvloed (zie ook Feldman \& $\mathrm{Ng}$, 2007). In de meeste studies blijkt werkontevredenheid de belangrijkste voorspeller voor baan-baanmobiliteit. Daarnaast is een belangrijke factor of werknemers ook daadwerkelijk van baan kúnnen veranderen (Trevor, 2001). 'Kunnen' wordt meestal opgevat als het hebben van de juiste capaciteiten om van baan te veranderen, waarbij de focus ligt op ontwikkelactiviteiten, zoals training en functie-uitbreiding of op 'ervaring met mobiliteit' (zie bijvoorbeeld Sanders et al., 2011c). Enerzijds bouwen werknemers door training, scholing en functie-uitbreiding aan een voor de externe arbeidsmarkt aantrekkelijk en dus gevraagd menselijk kapitaal. Zo creëren werknemers zelf meer mogelijkheden in de arbeidsmarkt en kunnen zij ook beter van baan veranderen. Anderzijds bouwen werknemers 
door ervaring op te doen met externe mobiliteit aan hun capaciteiten om ook in de toekomst van baan te veranderen. Zowel bij de bijdrage van training, ontwikkeling en functie-uitbreiding als bij de bijdrage van eerdere ervaring met externe mobiliteit aan het vermogen tot mobiliteit zijn echter kanttekeningen te plaatsen. Training, scholing en functie-uitbreiding maken werknemers vooral aantrekkelijker voor de arbeidsmarkt als deze ook gericht zijn is op kennis en vaardigheden die op de arbeidsmarkt gevraagd en gewaardeerd worden. Eerdere ervaring met externe mobiliteit draagt bij aan het mobiliteitsvermogen als die ervaring een leerzame was en bij voorkeur ook een positieve. Negatieve ervaringen met externe mobiliteit, bijvoorbeeld omdat die een gedwongen karakter had, kunnen immers ook een negatieve uitwerking hebben op het vermogen om van baan te veranderen. Negatieve ervaringen tasten het vertrouwen in het succesvol veranderen van baan in de toekomst aan en daarmee ook het vermogen tot veranderen.

In deze studie benaderen we 'kunnen' veranderen van baan of 'mobiliteitsvermogen' om voornoemde redenen vanuit (1) de individuele kansen op de arbeidsmarkt voor laagopgeleiden, en (2) het vertrouwen in het kunnen vinden van een nieuwe werkgever.

Studies in de traditie van de theorie van het geplande gedrag van Ajzen (Ajzen 1985, 1991, 2001) laten zien dat het vertrouwen van mensen om bepaald gedrag succesvol te kunnen vertonen een belangrijke voorspeller is van dat bepaalde gedrag. Dat geldt bijvoorbeeld voor de deelname aan ontwikkelactiviteiten (Fishbein \& Stasson, 1990; Maurer \& Tarulli, 1994; Collquitt et al., 2000; Tharenou, 2001; Borghans et al., 2007; McCarthy \& Garavan, 2008; Hurtz \& Williams, 2009). Eerder eigen onderzoek naar het stimuleren van scholingsintentie en -deelname onder laaggeschoolden laat zien dat een groter vertrouwen in de eigen competentie om een opleiding succesvol af te ronden (pre-training self-efficacy) een belangrijke factor is bij zowel het voorspellen van scholingsintentie als scholingsgedrag (Sanders et al., 2011a; Sanders et al., 2011b; Hazelzet et al., 2011). Zoveel als er is gepubliceerd over de positieve relatie tussen het vertrouwen in de eigen competentie om een training succesvol af te ronden, trainingsintentie en uiteindelijke trainingsdeelname, zo weinig is er bekend over de relatie tussen het vertrouwen in de eigen competentie om succesvol van baan te veranderen, vertrekintentie en uiteindelijke vrijwillige baanveranderingen. Studies naar deze relatie zijn schaars en studies naar deze relatie onder laaggeschoolde 45-plussers zijn zelfs, voor zover wij hebben kunnen nagaan, niet eerder uitgevoerd.

Vanwege de kwetsbare inzetbaarheid van laaggeschoolde oudere werknemers en het belang van mobiliteit en mobiliteitsvermogen voor verduurzaming van die inzetbaarheid is het van groot belang dat in deze kennislacune wordt voorzien. Deze studie beoogt hieraan een bijdrage te leveren door antwoord te geven op de volgende centrale vraagstelling:

Welke rol speelt het eigen vertrouwen in een succesvolle baan-baantransitie bij baanbaanmobiliteit van laaggeschoolde werknemers van 45 jaar en ouder?

We vertalen deze centrale vraagstelling in de volgende onderzoeksvragen voor deze studie. 


\section{Onderzoeksvragen:}

1. Op welke wijze hangt werktevredenheid samen met verandering van baan?

2. Op welke wijze hangt vertrouwen in eigen kunnen (self-efficacy) voor het vinden van een nieuwe werkgever samen met verandering van baan?

3. Verschillen de aangetroffen relaties tussen laag- en hoger opgeleiden?

\section{Willen: werktevredenheid}

Werktevredenheid is onder te verdelen in verschillende intrinsieke en extrinsieke dimensies (Kalleberg, 1977). Een meta-analyse van Cotton en Tuttle (1986) laat zien dat algemene werktevredenheid een sterke negatieve correlatie heeft met mobiliteit. Recente studies (Dorenbosch et al., 2011; Sanders et al., 2011c) bevestigen dat werkontevredenheid voor zowel laagopgeleiden als hoger opgeleiden de belangrijkste voorspeller is voor vertrekintentie en feitelijk verloop. Bij ontevreden laagopgeleiden blijkt de relatie tussen vertrekintentie en vertrekgedrag echter veel minder sterk dan bij ontevreden hoger geschoolden. In deze studie gaan we allereerst na in hoeverre deze relaties ook bij laagopgeleide 45-plussers worden gevonden. We toetsen daartoe hypothese $1 \mathrm{a}$ en $1 \mathrm{~b}$ :

Hypothese 1a: Bij laagopgeleide 45-plussers heeft werktevredenheid een minder sterke relatie met vertrekintentie dan bij hoger opgeleiden.

Hypothese 1b: Bij laagopgeleide 45-plussers heeft werktevredenheid een minder sterke relatie met baanverandering dan bij hoger opgeleiden.

Dorenbosch et al. (2011) concluderen dat, als werkontevredenheid bij laagopgeleiden minder vaak tot baanverandering leidt, dat dan voor laagopgeleiden ook naar andere of extra verklaringen gezocht moet worden voor immobiliteit dan bij hoger opgeleiden.

In deze studie zoeken we deze andere verklaringen van vertrouwen in het vinden van een nieuwe werkgever en in de reële kansen op de arbeidsmarkt.

\section{Kunnen: vertrouwen in het kunnen vinden van een nieuwe werkgever}

Een verklaringen voor de lagere mobiliteit van laagopgeleiden is mogelijk een gebrek aan vertrouwen in een succesvolle baan-baantransitie. Veel onderzoeken gebruiken de theorie van het geplande gedrag (Theory of Planned Behavior, TPB) als verklarend model voor uiteenlopende vormen van gedrag (Van Breukelen et al., 2004; Raemdonck, 2006; Van Hooft at al., 2010; Hazelzet et al., 2011). Centrale aanname in TPB is dat iemands intentie om bepaald gedrag te vertonen de determinant is van dat gedrag, waarbij intentie een indicator is voor de hoeveelheid moeite die iemand wil doen om het gedrag uit te voeren (Ajzen, 1985, 1991, 2001). Gedragsintenties worden volgens TPB beïnvloed door drie factoren: attitude (houding), subjectieve norm (verwachtingen van derden) en vertrouwen in eigen succesvol gedrag. Naarmate er in sterkere mate sprake is van deze factoren, wordt de intentie tot gedrag groter en neemt de kans dat het gedrag daadwerkelijk plaatsvindt toe. In dit onderzoek onderzoeken we de relatie tussen vertrouwen in het kunnen vinden van een nieuwe werkgever, vertrekintentie en daadwerkelijke verandering van baan. We toetsen daartoe de hypotheses $2 \mathrm{a}$ en $2 \mathrm{~b}$ : 
Hypothese 2a: Bij laagopgeleide 45-plussers heeft vertrouwen in het kunnen vinden van een nieuwe werkgever een positieve relatie met vertrekintentie.

Hypothese 2b: Bij laagopgeleide 45-plussers heeft vertrouwen in het kunnen vinden van een nieuwe werkgever een positieve relatie met feitelijke baanverandering.

Vertrouwen in eigen kunnen (self-efficacy) is een beïnvloedbaar concept dat onder andere kan worden versterkt door succeservaringen, door te leren van anderen, door verbale overtuiging of door een veranderde psychologische of emotionele staat. Onderzoek van Bandura $(1989,2001)$ laat zien dat vooral succeservaringen van groot belang zijn bij het vergroten van het vertrouwen. Omgekeerd blijkt dat ook het geval. Studies naar scholingsdeelname van lager opgeleiden laten bijvoorbeeld zien dat slechte ervaringen met leren bij laagopgeleiden het vertrouwen in eigen kunnen in relatie tot leren verzwakt en dat laagopgeleiden mede daardoor minder deelnemen aan formele scholing (zie o.a. Fouarge et al., 2010). Vergelijkbare studies naar baan-baanmobiliteit zijn echter zeldzaam. In een studie naar arbeidsmarkttransities van lager opgeleiden lieten Sanders et al. (2011c) zien dat externe mobiliteit in het verleden een voorspeller is voor vrijwillige externe mobiliteit. Dat zou kunnen wijzen op de waarde van een eerdere succeservaring met arbeidsmobiliteit voor vrijwillige externe mobiliteit in de toekomst. Omdat laagopgeleiden minder mobiel zijn dan hoger opgeleiden, is de verwachting dat ze minder goede ervaringen hebben met mobiliteit. Ook kan het zo zijn dat laagopgeleiden door eerdere slechtere ervaringen minder vertrouwen hebben in hun competentie om de eigen inzetbaarheid te verduurzamen door bijvoorbeeld 'mobiel te worden'. Deze verwachting vertaalt zich waarschijnlijk in lagere scores op vertrouwen in het kunnen vinden van een nieuwe werkgever. We toetsen dit in hypothese 3a:

Hypothese 3a: Bij laagopgeleide 45-plussers is het vertrouwen in het kunnen vinden van een nieuwe werkgever lager dan onder hoger opgeleide 45-plussers.

Omdat we willen weten of versterking van het vertrouwen in het vinden van een nieuwe werkgever ook specifiek bij laagopgeleiden leidt tot een grotere vertrekintentie en een grotere kans op baanverandering, gaan we vervolgens na of de relatie tussen vertrouwen in het kunnen vinden van een andere werkgever, vertrekintentie en baanverandering, zoals getoetst in hypotheses $2 \mathrm{a}$ en $2 \mathrm{~b}$, bij laagopgeleide 45-plussers sterker, zwakker of even sterk zijn als onder hoger opgeleide 45-plussers. Daartoe toetsen we de hypotheses 3b en 3c:

Hypothese 3b: Bij laagopgeleide 45-plussers is de positieve relatie tussen het vertrouwen in het kunnen vinden van een nieuwe werkgever en vertrekintentie sterker dan onder hoger opgeleide 45-plussers.

Hypothese 3c: Bij laagopgeleide 45-plussers is de positieve relatie tussen het vertrouwen in het kunnen vinden van een nieuwe werkgever en baanverandering sterker dan onder hoger opgeleide 45-plussers. 
Kunnen: mogelijkheden hebben op de externe arbeidsmarkt

Een andere verklaring voor de beperkte baan-baanmobiliteit onder laagopgeleide 45-plussers is dat laagopgeleiden een reëel beeld hebben van hun arbeidsmarktsituatie en de eigen perspectieven en dat zij dus ook goed weten dat zij minder kansen hebben op de arbeidsmarkt. Een studie van Trevor (2001) toont aan dat een tekort aan banen het daadwerkelijke vertrek inderdaad negatief beïnvloedt. Of het bewustzijn van beperktere mogelijkheden op de arbeidsmarkt een verklaring kan zijn voor de immobiliteit van laagopgeleide 45-plussers toetsen we in hypothese 4:

Hypothese 4: Laagopgeleide 45-plussers werken vaker in krimpsectoren dan hoger opgeleide 45-plussers.

Als blijkt dat laagopgeleide 45-plussers vaker in krimpsectoren werken dan hoger opgeleide 45-plussers, gaan we vervolgens na in hoeverre het werkzaam zijn in een krimpsector van invloed is op de vertrekintentie op T1 en de feitelijke baanverandering tussen $\mathrm{T} 1$ en $\mathrm{T} 2$.

\section{Methode}

\section{Data}

Deze studie is gebaseerd op data van de Study on Transitions in Employment, Ability and Motivation (STREAM). STREAM is een grootschalig longitudinaal onderzoek naar transities in arbeid van personen van 45 tot 64 jaar. Het hoofddoel van STREAM is de identificatie van omstandigheden waaronder 45-plussers (langer) in betaald werk participeren, met behoud van een goede gezondheid en een goede productiviteit. STREAM is een project van TNO, waarin nauw wordt samengewerkt met het VU Medisch Centrum en het Erasmus Medisch Centrum. ${ }^{2}$ Gegevens van STREAM bieden de mogelijkheid om een beter beeld te krijgen van de situatie van de laagopgeleide oudere werknemer en op welke wijze deze verschilt van die van middelbaar en hoogopgeleide werknemers. Voor meer informatie over methodologie, vragenlijst en beschrijvende resultaten van het STREAMonderzoek verwijzen we naar Ybema et al. ( 2011a).

\section{Steekproef}

De eerste twee metingen in het kader van het STREAM-onderzoek zijn uitgevoerd in 2010 en 2011. Verdere follow-up metingen vinden plaats in 2012 en 2013. Voor de dataverzameling wordt gebruikgemaakt van een internetpanel van Intomart GfK. Hieruit zijn naar leeftijd gestratificeerde steekproeven getrokken van ruim 12.000 werknemers, 1.000 zelfstandigen en 2.000 niet-werkenden van 45 jaar of ouder. Hoewel in het STREAM-onderzoek niet expliciet gestreefd is naar representativiteit, leert nadere analyse dat de STREAM-data op de meeste cellen voor de groep werknemers representatief is naar geslacht en opleiding. Een uitzondering vormt de leeftijdsgroep 60-64 jaar. Deze cel bevat naar verhouding meer laagopgeleide vrouwen en minder laagopgeleide en middelbaar opgeleide 
mannen dan de populatie. Voor deze studie maken we alleen gebruik van de data over werknemers.

De multipele lineaire regressieanalyses in deze studie zijn uitgevoerd op data uit de eerste meting onder 11.987 werknemers van 45 jaar of ouder. De longitudinale analyses (logistische regressies) op daadwerkelijke baanverandering tussen T1 en T2 zijn uitgevoerd op een bestand van 8.989 werknemers van 45 jaar of ouder.

\section{Variabelen}

De intentie tot vertrek is gemeten op T1 door werknemers te vragen of ze van plan zijn om in de komende twaalf maanden van baan te veranderen. De antwoordcategorie voor deze vraag loopt van 'zeker niet' tot 'zeker wel' op een 5-puntsschaal.

Vertrouwen (self-efficacy) in het kunnen vinden van een nieuwe werkgever is gemeten op T1 door werknemers te vragen of zij zelf denken in staat te zijn om de komende twaalf maanden een nieuwe werkgever te vinden. Ook hier is gebruikgemaakt van een 5-punts antwoordschaal die loopt van 'zeker niet' tot 'zeker wel'. Bij de formulering van vragen over het vertrouwen in eigen kunnen is gebruikgemaakt van de richtlijnen van Bandura (2006).

Baanverandering is gemeten op T2 door werknemers te vragen of zij in de afgelopen twaalf maanden van werkgever zijn veranderd. Werknemers konden hierop ja of nee antwoorden.

Reële arbeidsmarktkansen worden bepaald aan de hand van gegevens over de verwachte arbeidsmarktontwikkelingen tot 2016 voor de bedrijfssector waarin een werknemer op T1 werkzaam is. Of er sprake is van groei of krimp in een sector, bepaalt dan de reële arbeidsmarktkans. De indicator voor verwachte groei of krimp van de werkgelegenheid worden ontleend aan het rapport De arbeidsmarkt naar opleiding en beroep tot 2016 van het Researchcentrum voor Onderwijs en Arbeidsmarkt (ROA, 2011).

In dit onderzoek wordt gekeken naar verschillen tussen laagopgeleiden en middelbaar en hoger opgeleiden. Het opleidingsniveau is vastgesteld door respondenten te vragen wat de hoogst genoten opleiding is die zij met een diploma hebben afgerond. Respondenten konden kiezen uit zeven antwoordcategorieën lopende van 1: geen onderwijs/basisonderwijs tot 7: wo/doctoraal. Voor deze studie is een onderscheid gemaakt tussen twee groepen, namelijk laag opgeleiden en hoger opgeleiden. Laag opgeleiden zijn werknemers die over maximaal een vmbodiploma beschikken. Onder hoger opgeleiden worden de respondenten gerekend die ten minste een mbo-opleiding hebben afgerond.

In dit onderzoek wordt ten slotte gecontroleerd voor leeftijd en geslacht op T1. De leeftijd van de respondent wordt afgeleid van de geboortedatum. Leeftijd is gemeten als een continue variabele.

\section{Analyses}

De hypothesen voor deze studie worden allereerst bivariaat getoetst met behulp van Pearson-correlaties. Daarbij wordt gekeken naar de samenhang tussen het vertrouwen in het kunnen vinden van een nieuwe werkgever, vertrekintentie, feitelijke baanverandering, reële arbeidsmarktkansen, opleidingsniveau, geslacht en 
leeftijd. Hypothese 3a (bij laagopgeleide 45-plussers is het vertrouwen in het kunnen vinden van een nieuwe werkgever lager dan onder hoger opgeleide 45-plussers) en hypothese 4 (laagopgeleide 45-plussers werken vaker in krimpsectoren dan hoger opgeleide 45 -plussers) worden alleen bivariaat getoetst met behulp van Pearson-correlaties.

Hypothese 1a (bij laagopgeleide 45-plussers heeft werktevredenheid een minder sterke relatie met vertrekintentie dan bij hoger opgeleiden), hypothese 2a (bij laagopgeleide 45-plussers heeft het vertrouwen in het kunnen vinden van een nieuwe werkgever een positieve relatie met vertrekintentie) en hypothese $3 \mathrm{~b}$ (bij laagopgeleide 45-plussers is de positieve relatie tussen het vertrouwen in het kunnen vinden van een nieuwe werkgever en vertrekintentie sterker dan onder hoger opgeleide 45-plussers) toetsen we met een lineaire regressie van vertrekintentie op T1. We onderzoeken allereerst de directe verbanden van respectievelijk werktevredenheid en het vertrouwen in het kunnen vinden van een nieuwe werkgever op vertrekintentie en kijken vervolgens ook naar de tweeweg- en drieweg- interacties van opleidingsniveau op de relaties van werktevredenheid en het vertrouwen met vertrekintentie. In deze analyses zijn de scores op werktevredenheid en vertrouwen gecentreerd om hoge correlaties tussen de hoofdeffecten en de interactie-effecten te vermijden (Aiken \& West, 1991).

Hypothese $1 \mathrm{~b}$ (bij laagopgeleide 45-plussers heeft werktevredenheid een minder sterke relatie met baanverandering dan bij hoger opgeleiden), hypothese $2 \mathrm{~b}$ (bij laagopgeleide 45-plussers heeft vertrouwen in het kunnen vinden van een nieuwe werkgever een positieve relatie met feitelijke baanverandering) en hypothese $3 c$ (bij laagopgeleide 45-plussers is de positieve relatie tussen vertrouwen in het kunnen vinden van een nieuwe werkgever en baanverandering sterker dan onder hoger opgeleide 45-plussers) toetsen we met logistische regressies van feitelijke baanverandering tussen T1 en T2, waarbij alle predictoren zijn gemeten op T1.

Gezien de grote steekproefomvang beschouwen we een effect als statistisch significant wanneer de $\mathrm{p}$-waarde kleiner is dan ,01 $(=0,01)$.

\section{Resultaten}

Als eerste toetsen we hypothese 4 die stelt dat laagopgeleiden vaker werkzaam zijn in krimpsectoren. Tabel 1 geeft de Pearson-correlaties voor de indicator voor reële arbeidsmarktkansen en de overige variabelen in deze studie. We zien dat laagopgeleide werknemers weliswaar vaker werkzaam zijn in sectoren die in de afgelopen jaren zijn gekrompen dan hoger opgeleide werknemers, maar dat er in deze gekrompen sectoren voor de komende jaren juist meer groei te verwachten is. Hypothese 4 wordt op grond van deze resultaten verworpen. Laagopgeleide $45-$ plussers werken niet vaker of minder vaak in sectoren waar krimp in de werkgelegenheid wordt verwacht. Tabel 1 laat voorts zien dat de reële arbeidsmarktkansen niet of nauwelijks samenhangen met de werktevredenheid, het vertrouwen in het kunnen vinden van een nieuwe baan, de intentie om van baan te veranderen en de feitelijke baanverandering tussen $\mathrm{T} 1$ en $\mathrm{T} 2$. In de volgende analyses laten we reële arbeidsmarktkansen daarom verder buiten beschouwing. 
Tabel 1 Correlaties tussen de variabelen in het model en reële arbeidsmarktkansen op basis van groei/krimpverwachting 2011-2016

\begin{tabular}{|c|c|c|}
\hline Correlaties met groei/krimp & $\begin{array}{l}\text { Waargenomen groei of } \\
\text { krimp van sector TI in } \\
2006-2010\end{array}$ & $\begin{array}{l}\text { Verwachte groei of } \\
\text { krimp van sector TI in } \\
2011-2016\end{array}$ \\
\hline $\begin{array}{l}\text { Opleidingsniveau ( } \mathrm{I}=\text { laag; } \\
0=\text { middelbaar of hoog) }\end{array}$ &,$- 138 * *$ &, $128 * *$ \\
\hline Geslacht ( 1 = man; 2 = vrouw $)$ &, $327 * *$ & , 154 ** \\
\hline Leeftijd (in jaren) &, $053 * *$ &,$- 033 * *$ \\
\hline Werktevredenheid &, $039 * *$ &, 014 \\
\hline $\begin{array}{l}\text { Self-efficacy inzake baanverande- } \\
\text { ring }\end{array}$ & ,007 &, $021 *$ \\
\hline $\begin{array}{l}\text { Intentie om van baan te verande- } \\
\text { ren }\end{array}$ &, 007 &,- 006 \\
\hline $\begin{array}{l}\text { Feitelijke baanverandering tussen } \\
\text { TI en T2 }\end{array}$ &,$- 028 * *$ &, $034 * *$ \\
\hline
\end{tabular}

$* \mathrm{p}<, 05 ; * * \mathrm{p}<, 0$ I; $\mathrm{N}$ voor correlatie met feitelijke baanverandering $=8.933$, overige $\mathrm{N}$ varieert van II.656 tot II.749

In tabel 2 geven we eerst een overzicht van de Pearson-correlaties voor de afhankelijke, onafhankelijke en covariaten in deze studie. Tabel 2 laat zien dat vertrouwen in het kunnen vinden van een nieuwe werkgever een matige positieve samenhang vertoont met de intentie tot baanverandering $(r=0,29 ; \mathrm{p}<, 001)$. Daarnaast is er een zwakke positieve samenhang tussen vertrouwen en feitelijke baanverandering tussen T1 en T2 $(r=0,10 ; p<, 001)$. Een lager opleidingsniveau vertoont een zwak negatief verband met vertrouwen in het kunnen vinden van een nieuwe werkgever $(r=-0,15 ; p<, 001$, zie tabel 1$)$. Verder valt op dat het vertrouwen in het kunnen vinden van een nieuwe werkgever veel lager is naarmate de respondenten ouder zijn.

Hypothese 3a, die stelt dat laagopgeleide 45-plussers een lagere score hebben op het vertrouwen in het kunnen vinden van een nieuwe werkgever dan hoger opgeleiden, wordt daarmee bevestigd. Laagopgeleide 45-plussers hebben inderdaad een geringer vertrouwen in de eigen capaciteiten om een nieuwe werkgever te vinden dan hoger opgeleide 45-plussers.

Verder blijkt uit tabel 2 dat een lager opleidingsniveau samenhangt met een geringere intentie tot baanverandering $(r=-0,09 ; p<, 001)$, maar niet met een kleinere kans op feitelijke baanverandering. Lager opgeleide 45 -plussers in onze data vertonen dus zowel een geringere intentie tot baanverandering als een geringer vertrouwen in het kunnen vinden van een nieuwe werkgever, maar ze veranderen niet minder vaak van baan dan hoger opgeleide 45-plussers.

In tabel 3 worden de resultaten weergegeven van een multipele lineaire regressieanalyse van de intentie om van baan te veranderen, bestaande uit vier modellen. In de eerste stap zijn de hoofdeffecten van opleiding, geslacht en leeftijd opgenomen, en in de tweede stap de hoofdeffecten van werktevredenheid en vertrouwen. In de derde stap worden de tweeweginteracties tussen opleiding, werktevre- 
Tabel 2 Correlaties tussen de variabelen in het model

\begin{tabular}{|c|c|c|c|c|c|c|c|}
\hline & I & 2 & 3 & 4 & 5 & 6 & 7 \\
\hline $\begin{array}{l}\text { Opleidingsniveau (I = laag; } 0 \text { = middel- } \\
\text { baar of hoog) }\end{array}$ & 1,000 & & & & & & \\
\hline 2 Geslacht $(I=\operatorname{man} ; 2$ = vrouw $)$ &, $043 * *$ & $\mathrm{I}, 000$ & & & & & \\
\hline 3 Leeftijd (in jaren) &, $075^{* *}$ &,$- 035 * *$ & 1,000 & & & & \\
\hline 4 Werktevredenheid &,- 017 &, $062 * *$ &, $020 *$ & $\mathrm{I}, 000$ & & & \\
\hline 5 Self-efficacy inzake baanverandering &,$- 153 * *$ &,$- 026 * *$ &,$- 410 * *$ &, $068 * *$ & 1,000 & & \\
\hline 6 Intentie om van baan te veranderen &,$- 093 * *$ &,- 003 &,$- 267 * *$ &,$- 359 * *$ &, $293 * *$ & 1,000 & \\
\hline $\begin{array}{l}7 \text { Feitelijke baanverandering tussen TI } \\
\text { en } T 2(I=\text { ja; } 0=\text { nee })\end{array}$ &,- 006 &, 016 &,$- 080 * *$ &,$- 077 * *$ &, $102 * *$ &, $246 * *$ & 1,000 \\
\hline
\end{tabular}

Tabel 3 Lineaire regressie met als afhankelijke variabele de intentie om van baan te veranderen op $\mathrm{T} 1$

\begin{tabular}{|c|c|c|c|c|}
\hline & $\begin{array}{l}\text { Stap I } \\
\text { bèta }\end{array}$ & $\begin{array}{l}\text { Stap } 2 \\
\text { bèta }\end{array}$ & $\begin{array}{l}\text { Stap } 3 \\
\text { bèta }\end{array}$ & $\begin{array}{l}\text { Stap } 4 \\
\text { bèta }\end{array}$ \\
\hline Opleidingsniveau ( $\mathrm{I}=$ laag; 0 = middelbaar of hoog) &,$- 073 * *$ &,$- 05 \mid * *$ &,- 055 &,$- 055 * *$ \\
\hline Geslacht $(I=$ man; $2=$ vrouw $)$ &,- 009 &, $024 *$ &, 019 &, $019 *$ \\
\hline Leeftijd (in jaren) &,$- 262 * *$ &,$- 154 *$ &,- 149 &,$- 149 * *$ \\
\hline Werktevredenheid & &,$- 375 * *$ &,- 392 &,$- 392 * *$ \\
\hline Self-efficacy inzake baanverandering & &, $246 *$ &, 266 &, $265 * *$ \\
\hline Interactie werktevredenheid $\mathrm{x}$ self-efficacy & & &,- 157 &,$- 147 * *$ \\
\hline Interactie werktevredenheid $\mathrm{x}$ laagopgeleid & & &, 021 &, 018 \\
\hline Interactie self-efficacy $\times$ laagopgeleid & & &,- 014 &,- 013 \\
\hline $\begin{array}{l}\text { Interactie werktevredenheid } x \text { self-efficacy } x \text { laag- } \\
\text { opgeleid }\end{array}$ & & & &,- 018 \\
\hline $\mathrm{N}$ & 11.844 & II.844 & II.844 & 11.844 \\
\hline$R^{2}$ & $0,08 * *$ & $0,25 * *$ & $* \quad 0.28 *$ & $* * \quad 0,28 * * *$ \\
\hline$\Delta \mathrm{R}^{2}$ & & $0,18 *$ & 0,03 & 0,00 \\
\hline
\end{tabular}

$* \mathrm{p}<, 05 ; * * \mathrm{p}<, 0$ I

denheid en vertrouwen opgenomen en in de vierde en laatste stap nemen we de drieweginteractie tussen de variabelen op.

De resultaten in tabel 3 tonen aan dat, conform de correlaties in tabel 1 , zowel laag opleidingsniveau $(\beta=-0,055 ; \mathrm{p}<, 001)$ als vertrouwen in het kunnen vinden van een nieuwe werkgever $(\beta=0,265 ; \mathrm{p}<, 001)$ als werktevredenheid $(\beta=-0,392$; $\mathrm{p}<, 001)$ samenhangen met de intentie tot baanverandering. Een grotere mate van vertrouwen in het kunnen vinden van een nieuwe werkgever hangt positief samen met een grotere intentie tot baanverandering, en een grotere werktevredenheid hangt negatief samen met een grotere intentie tot baanverandering. 
Er zijn echter geen verschillen tussen laag- en hoger opgeleiden in de gevonden relaties tussen vertrouwen (self-efficacy) en intentie tot baanverandering en werktevredenheid en intentie tot baanverandering. Het toevoegen van de interactietermen tussen opleidingsniveau en vertrouwen $(\beta=-0,014 ; \mathrm{p}=, 131)$ en tussen opleidingsniveau en werktevredenheid $(\beta=0,021 ; \mathrm{p}=, 030)$ draagt niet significant (op 1\%-niveau) bij aan de regressie van de intentie om van baan te veranderen. Er zijn dus geen verschillen tussen laag- en hoger opgeleiden in de relatie tussen vertrouwen en intentie tot baanverandering en tussen werktevredenheid en intentie tot baanverandering. Wel draagt de interactie tussen vertrouwen en werktevredenheid bij aan de regressie van de intentie tot baanverandering $(\beta=-0,157, p<.001)$. Deze interactie geeft aan dat vooral wanneer het vertrouwen in het kunnen vinden van een nieuwe werkgever hoog is, ontevredenheid met het werk samenhangt met de intentie om van baan te veranderen.

Dat betekent dat hypothese $2 \mathrm{a}$, die stelt dat er bij laagopgeleide 45-plussers een positieve relatie is tussen vertrouwen in het kunnen vinden van een nieuwe werkgever en vertrekintentie, wordt bevestigd. Hypothese $1 \mathrm{a}$, die stelt dat bij laagopgeleide 45-plussers werktevredenheid een minder sterke relatie heeft met vertrekintentie dan bij hoger opgeleiden, en hypothese $3 \mathrm{~b}$, die stelt dat bij laagopgeleide 45-plussers de positieve relatie tussen vertrouwen in het kunnen vinden van een nieuwe werkgever en vertrekintentie sterker is dan onder hoger opgeleide 45-plussers, worden beide echter verworpen.

Om hypothese $1 b, 2 b$ en $3 c$ te toetsen voeren we multipele logistische regressieanalyses uit van daadwerkelijke baanverandering tussen T1 en T2. Deze analyses betreffen alleen personen die aan beide metingen hebben deelgenomen, op beide metingen werknemer waren en geen missende waarden hadden op de onderzochte variabelen $(\mathrm{N}=8.989)$. In de eerste stap zijn de hoofdeffecten van opleiding, geslacht en leeftijd opgenomen, in de tweede stap de hoofdeffecten van werktevredenheid en vertrouwen, in de derde stap de tweeweginteracties tussen opleiding, werktevredenheid en vertrouwen, en in de vierde stap de drieweginteractie tussen deze variabelen. Uit de eerste analyses bleek dat op 1\%-niveau geen van de interactietermen significant bijdroeg aan de regressie van baanverandering. De interactie tussen werktevredenheid en vertrouwen in het vinden van een nieuwe baan was niet significant. De interacties blijven om voornoemde redenen in de verdere regressieanalyse van feitelijke baanverandering buiten beschouwing. Hypothese $1 \mathrm{~b}$, die stelt dat werktevredenheid bij laagopgeleide 45-plussers een minder sterke relatie heeft met baanverandering dan bij hoger opgeleide 45 -plussers, wordt bevestigd. Dat geldt niet voor hypothese $3 c$, die stelt dat de positieve relatie tussen het vertrouwen in het kunnen vinden van een nieuwe werkgever en baanverandering bij laagopgeleide 45-plussers sterker is dan onder hoger opgeleide 45-plussers. Deze hypothese wordt verworpen.

De resultaten van de uiteindelijke analyses zijn weergegeven in tabel 4 . We gaan na of de intentie om van baan te veranderen de effecten van tevredenheid en vertrouwen medieert. In de eerste stap zijn de (hoofd)effecten van opleiding, geslacht en leeftijd opgenomen, in de tweede stap de (hoofd)effecten van werk- 
Tabel $4 \quad$ Logistische regressie met als afhankelijke variabele baanverandering tussen $\mathrm{T} 1$ en $\mathrm{T} 2$ (alle predictoren op $\mathrm{T} 1$ gemeten)

\begin{tabular}{|c|c|c|c|}
\hline & $\begin{array}{l}\text { Stap I } \\
\text { OR }\end{array}$ & $\begin{array}{l}\text { Stap } 2 \\
\text { OR }\end{array}$ & $\begin{array}{l}\text { Stap } 3 \\
\text { OR }\end{array}$ \\
\hline Opleidingsniveau ( $\mathrm{I}=$ laag; 0 = middelbaar of hoog) & ,986 & 1,085 & 1,223 \\
\hline Geslacht $(I=$ man; 2 = vrouw $)$ & $\mathrm{I}, \mathrm{I} 45$ & 1,236 & 1,134 \\
\hline Leeftijd (in jaren) &, $924 * *$ &, $955 * *$ & ,985 \\
\hline Werktevredenheid & & ,631 ** & $\mathrm{I}, 058$ \\
\hline Self-efficacy baanverandering & & $|, 49| * *$ & $1,231 * *$ \\
\hline Intentie om van baan te veranderen & & & $2,326 * *$ \\
\hline $\mathrm{N}$ & 8.989 & 8.989 & 8.989 \\
\hline Nagelkerke $\mathrm{R}^{2}$ & $0,02 * *$ & $0,07 * *$ & $0,16 * *$ \\
\hline$\Delta$ Nagelkerke $\mathrm{R}^{2}$ & & $0,04 * *$ & $0,09 * *$ \\
\hline
\end{tabular}

tevredenheid en vertrouwen, in de derde stap de intentie om van baan te veranderen op de eerste meting.

Uit tabel 4 blijkt dat de kans op daadwerkelijke baanverandering tussen beide metingen lager is naarmate werknemers ouder zijn, en hoger wanneer werknemers minder tevreden zijn met hun werk en wanneer zij meer vertrouwen hebben in het vinden van een nieuwe werkgever. Hypothese $2 \mathrm{~b}$, die stelt dat bij laagopgeleide 45-plussers het vertrouwen in het kunnen vinden van een nieuwe werkgever een positieve relatie heeft met feitelijke baanverandering, wordt daarmee bevestigd. Wanneer de intentie om van baan te veranderen wordt toegevoegd aan de regressie, verdwijnen de effecten van leeftijd en werktevredenheid. Het effect van vertrouwen (self-efficacy) blijft grotendeels bestaan. Dit betekent dat de intentie om van baan te veranderen het effect van werktevredenheid medieert.

Figuur 1 geeft een overzicht van de uitkomsten van de gepresenteerde analyses: werktevredenheid verlaagt de intentie om van baan te veranderen en via die intentie de kans dat werknemers daadwerkelijk van baan veranderen. De negatieve relatie van werktevredenheid met de intentie om van baan te veranderen wordt versterkt door een groot vertrouwen. Verder hebben laagopgeleiden een lagere intentie om van baan te veranderen (maar ze doen dit niet daadwerkelijk minder vaak). Ten slotte zijn werknemers die zichzelf in staat achten om een nieuwe werkgever te vinden, sterker van plan om van baan te veranderen, en dit vertrouwen draagt zowel direct als indirect bij aan een hogere kans om daadwerkelijk van baan te veranderen.

\section{Discussie}

In diverse recente studies is aangetoond dat laagopgeleiden (Gesthuizen \& Dagevos, 2005; Zwinkels et al., 2009; Fouarge et al., 2010; Sanders et al., 2011c) en ook oudere werknemers (Ybema \& Geuskens, 2011) in het algemeen minder vrij- 
Figuur 1 Self-efficacy, werktevredenheid en hun invloed op baanbaantransities

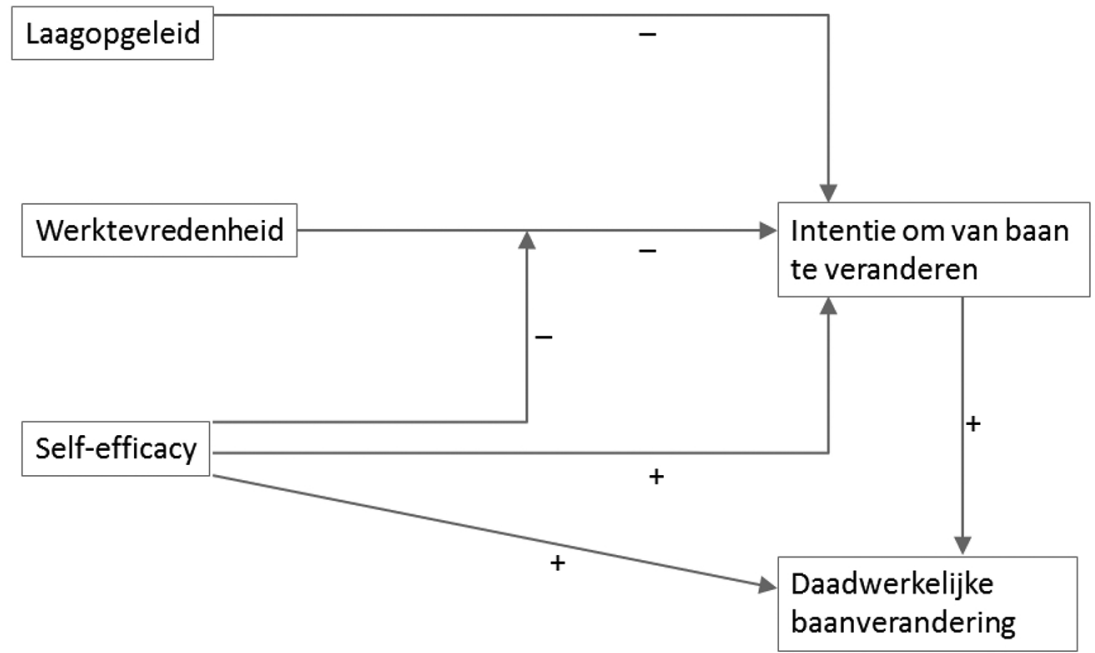

willige baan-baanmobiliteit laten zien dan hoger opgeleiden en jongere werknemers. Een vraag die in al deze studies onbeantwoord blijft, is de vraag hoe vrijwillige baan-baanmobiliteit juist bij oudere laaggeschoolde werknemers vergroot zou kunnen worden, anders dan via bekende 'push'-factoren als baanontevredenheid en conflicten met collega's en/of leidinggevenden. Het antwoord op deze vraag heeft een grote praktische relevantie voor makers van arbeidsmarktbeleid op landelijk, sectoraal en regionaal niveau en voor makers van HRM-beleid in bedrijven en instellingen. Zowel arbeidsmarkt- als HRM-beleid richt zich immers steeds meer op verduurzaming van inzetbaarheid. Tijdige baan-baanmobiliteit, geheel of gedeeltelijk, bijvoorbeeld vanuit fysiek zware beroepen en banen naar minder fysiek belastende banen of door combinaties van fysiek zware en fysiek minder zware banen te combineren tot één 'ideale' baan, kan aan die duurzame inzetbaarheid een belangrijke bijdrage leveren.

In deze studie onder werknemers van 45 tot 64 jaar laten we allereerst zien dat laagopgeleide werknemers niet minder vaak of vaker mobiel zijn dan hoger opgeleide werknemers. Wel hebben lager opgeleide 45-plussers minder vertrouwen in een succesvolle baan-baantransitie dan hoger opgeleiden en hebben zij minder vaak de intentie om van baan te veranderen. Dat wijst op een hogere mate van (door omstandigheden) gedwongen baan-baantransities door laagopgeleide 45plussers. Er gaat immers geen eigen intentie vooraf aan de gerealiseerde baanbaantransitie. De resultaten van deze studie laten vervolgens bij zowel laagopgeleide als hoger opgeleide 45-plussers een vergelijkbare positieve relatie zien tussen het vertrouwen in een succesvolle baan-baantransitie en de intentie om van baan te veranderen enerzijds en feitelijke baanverandering anderzijds. Daar- 
mee laat deze studie zien dat het bevorderen van het vertrouwen (self-efficacy) om een succesvolle baanverandering door te maken een eerste stap kan zijn in het bewerkstelligen van meer vrijwillige baan-baantransities van zowel laagopgeleide als hoger opgeleide oudere werknemers.

Deze resultaten betekenen voor het arbeidsmarkt en HRM beleid dat tot doel heeft om vooral ook aan de onderkant van de (interne) arbeidsmarkt de 'dynamiek' te stimuleren in termen van meer vrijwillige arbeidsmobiliteit onder laagopgeleide 45 plussers, er allereerst zou moeten worden ingezet op het versterken van het vertrouwen van werknemers om een baantransitie ook succesvol te kunnen maken. Een interessante vervolgvraag is dan hoe dat vertrouwen op succesvolle baan-baantransities, specifiek bij laagopgeleide 45 plussers, zou kunnen worden bevorderd.

Onderzoek van Bandura (2001) laat zien dat vooral de eigen succeservaringen daarbij van groot belang zijn, maar ook het leren van anderen (succesverhalen en goede praktijken), verbale overtuiging of een veranderde psychologische of emotionele staat kunnen een bijdrage leveren. Het is dus van belang om succesvolle baantransities, hoe klein die soms ook zijn, nadrukkelijk te adresseren en deze samen met medewerkers zelf ook te beleven. Daarbij valt te denken aan functieuitbreidingen, promotie, functieveranderingen, tijdelijk werken op een andere locatie, invallen in een ander team, et cetera. Dergelijke succesvolle (gedeeltelijke) 'transities' kunnen immers bijdragen aan het vertrouwen dat laagopgeleide 45 -plussers nodig hebben en dat hen zou kunnen stimuleren om mobiel te worden. In hoeverre laagopgeleide 45-plussers een andere benadering vragen dan hoger opgeleide, bijvoorbeeld vanwege een verschil in eigen succeservaringen, succesverhalen van anderen of een andere emotionele staat, zal verder onderzoek kunnen uitwijzen. Een interessante vervolgvraag is dan ook nog de vraag of en in hoeverre deze vrijwillige baan-baantransities dan bijdragen aan de verduurzaming van de inzetbaarheid van laagopgeleide 45 -plussers.

Opvallend in deze studie is de sterke negatieve relatie tussen leeftijd en het vertrouwen in het kunnen vinden van een nieuwe werkgever. Naarmate de leeftijd toeneemt, hebben werknemers steeds minder geloof in het kunnen vinden van een nieuwe werkgever. Eerder onderzoek onder laagopgeleiden laat zien dat zij veel meer dan hoger opgeleiden gericht zijn op de interne arbeidsmarkt en op interne mobiliteit (Sanders \& De Grip, 2004; Raemdonck, 2006; Sanders et al., 2011c; Dorenbosch et al., 2011). Een verklaring daarvoor zou kunnen zijn dat oudere en laagopgeleide werknemers feitelijk minder kansen hebben op de externe arbeidsmarkt en dat zij dat ook als zodanig ervaren. Dat vertaalt zich dan in een lager vertrouwen en een lagere intentie om van baan te veranderen. In deze studie hebben we daarom ook gekeken naar de relatie tussen de reële arbeidsmarktkansen op basis van gegevens over de verwachte ontwikkeling van de werkgelegenheid in de sectoren waar werknemers werkzaam zijn, en vertrouwen. Er blijkt echter geen relatie tussen vertrouwen en de reële arbeidsmarktkansen op het niveau van sectoren.

Op basis van deze studie komen we tot de slotconclusie dat het vergroten van het vertrouwen in de mogelijkheid van verandering van werkgever een belangrijke bijdrage zou kunnen leveren aan de verduurzaming van de inzetbaarheid van oudere 
laagopgeleiden. Meer vertrouwen in het succesvol kunnen veranderen van werkgever (vrijwillige externe mobiliteit) lijkt er in ieder geval toe bij te dragen dat de intentie om van baan te veranderen toeneemt en de kans op een feitelijke (vrijwillige) baan-baanverandering toeneemt.

Deze studie kent sterke punten in de zin dat het een grootschalig onderzoek is bij een heterogene groep 45-plussers. Bovendien zijn de cross-sectionele relaties tussen de psychologische variabelen aangevuld met een prospectieve analyse van feitelijk gedrag. Een beperking van het onderzoek is dat STREAM alleen op 45-plussers is gericht. Rest ons dus in ieder geval de vraag in welke mate de bevindingen in deze studie ook gelden voor jongere laagopgeleiden. Voor hen zijn wellicht andere relaties te verwachten. Vervolgonderzoek op andere data dan de STREAMdata zal dit mogelijk kunnen verduidelijken.

\section{Noten}

1 In deze studie hanteren we de term laagopgeleiden voor werknemers met opleidingsniveau mavo, eerste drie jaar havo/vwo, mulo, ulo, vmbo en lager.

2 STREAM wordt gefinancierd met een subsidie van het ministerie van Sociale Zaken en Werkgelegenheid aan TNO in het kader van de Rijksbijdrage en het Maatschappelijk Programma Arbeidsomstandigheden (MAPA).

\section{Literatuur}

Aiken, L.S. \& West, S.G. (1991). Multiple regression: Testing and interpreting interactions. Newbury Park, CA: Sage.

Ajzen, I. (1985). From intentions to actions: A theory of planned behavior. In J. Kuhi \& J. Beckmann (eds.), Action-control: From cognition to behavior (pp. 11-39). Heidelberg: Springer.

Ajzen, I. (1991). The theory of planned behavior. Organizational Behavior and Human Decision Processes, 50, 179-211.

Ajzen, I. (2001). Nature and operation of attitudes. Annual Review of Psychology, 52, 27-58.

Bandura, A. (1989). Human agency in social cognitive theory. American Psychologist, 44, $1175-1184$.

Bandura, A. (2001). Social cognitive theory: An agentive perspective. Annual Review of Psychology, 52, 1-26.

Bandura, A. (2006). Guide for constructing self-efficacy scales. In T. Urdan \& F. Pajares (eds.), Self-efficacy beliefs of adolescents (pp. 307-337). Charlotte, NC: Information Age Publishing.

Beer, P.T. de (2006). Perspectieven voor de laagopgeleiden. Tijdschrift voor Arbeidsvraagstukken, 22, 218-233.

Borghans, L., Golsteyn, B. \& Grip, A. de (2007). Werkend Leren. Economisch Statistische Berichten, 92, 260-263.

Breukelen, W. van, Vlist, R. van der \& Steensma, H. (2004). Voluntary employee turnover: Combining variables from the 'traditional' turnover literature with the theory of planned behavior. Journal of Organizational Behavior, 25, 893-914.

CBS (2008). Gezondheid en zorg in cijfers. Den Haag: Centraal Bureau voor de Statistiek. 
CBS (2011). Statline Databank. Den Haag: Centraal Bureau voor de Statistiek. Geraadpleegd via http://statline.cbs.nl op 11 januari 2012.

Colquitt, J.A., LePine, J.A. \& Noe, R.A. (2000). Toward an integrative theory of training motivation: A meta-analytic path analysis of 20 years of research. Journal Of Applied Psychology, 85, 678-707.

Cotton, J.L. \& Tuttle, J.M. (1986). Employee turnover: A meta-analysis and review with implications for research. The Academy of Management Review, 11, 55-70.

Dorenbosch, L., Huiskamp, R. \& Smulders, P. ( 2011). De relatie tussen baanontevredenheid en vertrekintenties: maakt opleiding een verschil? Tijdschrift voor Arbeidsvraagstukken, 27, 77-93.

Europese Commissie (2008). Demographic Trend, Socio-Economic Impacts and Policy Implications in the European Union - 2007. Directorate-General Employment, Social Affairs and Equal Opportunities Unit E1 - Social and Demographic Analysis.

Feldman, D. C. \& Ng, T.W.H. (2007). Careers: Mobility, embeddedness, and success. Journal of Management, 33, 350-377.

Fishbein, M. \& Stasson, M. (1990). The role of desires: Self-predictions and perceived control in the prediction of training session attendance. Journal of Consumer Psychology, 20, 173-198.

Fouarge, D., Schils, T. \& Grip, A. de (2010). Why do low-educated workers invest less in further training? ROA Research Memorandum 2010/10. Maastricht: Researchcentrum voor Onderwijs en Arbeidsmarkt.

Gesthuizen, M. \& Dagevos, J. (2005). Arbeidsmobiliteit in goede banen: Oorzaken van baanen functiewisselingen en gevolgen voor de kenmerken van het werk. Den Haag: Sociaal en Cultureel Planbureau.

Görlich, D. \& Grip, A. de (2007). Human capital depreciation during family-related career interruptions in male and female occupations. Maastricht: Researchcentrum voor Onderwijs en Arbeidsmarkt.

Grip, A. de \& Loo, J. van (2002). The economics of skills obsolescence: a review. In A. de Grip, J. van Loo \& K. Mayhew (eds.), The economics of skills obsolescence (pp. 1-26). Research in Labor Economics, nr. 21. Greenwich, CT: JAI Press.

Hazelzet, A., Sanders, J., Langelaan, S., Giesen, F. \& Keijzer, L. (2011). Stimuleren van scholing bij lager opgeleide werknemers. Hoofddorp: TNO.

Henkens, K., Dalen, H.P. van \& Solinge, H. van (2009). De vervagende grens tussen werk en pensioen - Over doorwerkers, doorstarters en herintreders. Amsterdam: KNAW Press.

Hooft, E.A.J. van, Wesdorp, P., Duinkerken, G. \& Geuns, R. van (2010). Het heft in eigen hand: Achtergrondstudie sturen op zelfsturing. Den Haag: Raad voor Werk en Inkomen (RWI).

Hooftman, W., Klauw, M. van der, Klein Hesselink, J., Terwoert, J., Jongen, M., Kraan, K., Wevers, C., Houtman, I. \& Koppes, L. (2011). Arbobalans 2011: Kwaliteit van arbeid, effecten en maatregelen in Nederland. Hoofddorp: TNO.

Hurtz, G. M. \& Williams, K. J. (2009). Attitudinal and motivational antecedents of participation in voluntary employee development activities. Journal of Applied Psychology, 94, 635-653.

Kalleberg, A.L. (1977). Work values and job rewards: A theory of job satisfaction. American Sociological Review, 42, 124-143.

Kraan, K., Wevers, C., Geuskens, G. \& Sanders J. (2011). Monitor Duurzame Inzetbaarheid - Resultaten 2010 en Methodologie. Hoofddorp: TNO.

Maurer, T.J. \& Tarulli, B.A. (1994). Investigation of perceived environment, perceived outcome, and person variables in relationship to voluntary development activity by employees. Journal of Applied Psychology, 79, 3-14. 
McCarthy, A. \& Garavan, T. (2008). Team learning and metacognition: Implications for human resource development. Advances in Developing Human Resources, 10, 509-524.

Nicoletti, C. \& Peracchi, F. (2001). Aging in Europe: What can we learn from the Europanel? In T. Boeri, A. Börsch-Supan, A. Bruguavini, R. Disney, A. Kapteyn \& F. Peracchi (eds.), More information, less ideology - Assessing the long-term sustainability of European pensions systems: Data requirements, analysis and evaluations (pp. 153-340). Boston/ Dordrecht/London: Kluwer.

Otten, F., Arts, K., Siermann, C. \& Ybema, J.F. (2010). Ouderen op de arbeidsmarkt. In J. Sanders, H. Lautenbach, P. Smulders \& H.-J. Dirven (red.), Alle hens aan dek: Nietwerkenden in beeld gebracht. (pp. 59-89) Hoofddorp/Heerlen: TNO/CBS.

Phillipson, C. \& Smith, A. (2005). Extending working life: A review of the research literature. Leeds: Department for Work and Pensions.

Raemdonck, I. (2006). Self-directedness in learning and career processes: A study in lower-qualified employees in Flanders. Proefschrift Universiteit Gent.

ROA (2011). De arbeidsmarkt naar opleiding en beroep tot 2016. Maastricht: Researchcentrum voor Onderwijs en Arbeidsmarkt.

Sanders, J. \& Grip, A. de (2004). Training, task flexibility and the employability of lowskilled workers. International Journal of Manpower, 25, 73-89.

Sanders, J., Hazelzet, A. \& Cielen, P. (2011a). Toch een opleiding. Opleiding en Ontwikkeling, 24(5), 44-49.

Sanders, J., Oomens, S., Hazelzet, A. \& Blonk, R. (2011b). Explaining lower educated worker's training intentions. Journal of Workplace Learning, 23, 402-416.

Sanders, J., Wijk, E. van, Dorenbosch, L. \& Blonk, R. (2011c). Arbeidsmarkttransities van laagopgeleiden. In W. Smits, J. Sanders, R. van Gaalen \& J.-F. Ybema (red.), Dynamiek op de Nederlandse Arbeidsmarkt: De focus op kwetsbare groepen (pp. 43-57). Den Haag/ Hoofddorp: CBS/TNO.

Tharenou, P. (2001). Going up? Do traits and informal social processes predict advancing in management? Academy of Management Journal, 44, 1005-1017.

Trevor, C.O. (2001). Interactions among actual ease-of-movement determinants and job satisfaction in the prediction of voluntary turnover. The Academy of Management Journal, 44, 621-638.

Vries, R. de, Wolbers, M. \& Velden, R. van der (2004). De arbeidsmarktpositie van schoolverlaters en werkenden zonder startkwalificatie. Den Haag: Raad voor Werk en Inkomen (RWI).

Ybema, J.F. \& Geuskens, G. (2011). Transities op de arbeidsmarkt van oudere werknemers. In W. Smits, J. Sanders, R. van Gaalen \& J.F. Ybema (red.), Dynamiek op de Nederlandse Arbeidsmarkt: De focus op kwetsbare groepen (pp. 207-225). Den Haag/ Hoofddorp: CBS/TNO.

Ybema, J.F., Geuskens, G. \& Heuvel, S. van den (2011a). Study on Transitions in Employment, Ability and Motivation (STREAM): Methodologie en eerste resultaten 2010. TNOrapport 031.21205/01.03. Hoofddorp: TNO.

Ybema, J.F., Geuskens, G. \& Heuvel, S. van den (2011b). Duurzame inzetbaarheid van ouderen: Resultaten van de eerste meting van STREAM. Hoofddorp: TNO.

Zwinkels, W., Ooms, D. \& Sanders, J. (2009). Omvang, aard en achtergronden van baanbaan-mobiliteit. Den Haag: Raad voor Werk en Inkomen (RWI). 